\title{
Land ownership reform in context of neoclassical and political economy potential
}

\author{
Makarov Anatolij Nikolaevich \\ NChI Department of economic theory and economic policy \\ Kazan Federal University, \\ Kazan, Russia \\ makarovfksu@yandex.ru
}

\author{
Mustafina Lilia Rashidovna \\ NChI Department of Foreign Languages \\ Kazan Federal University, \\ Kazan, Russia
}

LRMustafina@kpfu.ru

\author{
Maksutina Elena Vladimirovna \\ NChI Department of economic theory and economic policy \\ Kazan Federal University, \\ Kazan, Russia \\ lena.betty@mail.ru
}

\author{
Zhunussov Bauyrzhan Arystanovich \\ Aktobe Regional State University named after K. Zhubanov \\ Republic of Kazakhstan, Aktobe \\ uch_sovetargu@mail.ru
}

\begin{abstract}
The article deals with the conceptual foundations and consequences of the land property reform implemented since the $1990 \mathrm{~s}$, and the constructive concept of land property reform is proposed. It is shown that the current rules of land reform stimulate such negative phenomena as 1) the formation of legal owners who expect to receive parasitic incomes, 2) the development of a speculative land market, 3) the shadow economy expansion of the economic realization of land ownership. At the same time, the role of the weakest link in the Russian agrarian economy in the coming years is claimed by land ownership relations, overcoming the crisis processes in the agricultural sector and the formation of effective land relations are possible only on the basis of an effective national policy in the field of land property, taking into account food security and national interests. It is proved that the constructive position in the current situation in the field of land ownership relations is associated with a strong rejection of ultra-liberalist postulates and the positive development of the land reform correction concept affecting the conflicting interests of different subjects, and, principally direct producers of agricultural products; imputation of ownership and land use to business entities is objectively determined by criteria of maximizing efficiency (maximizing the value of the target function) and has no connection with the form of ownership.
\end{abstract}

Keywords - land ownership, speculation, latifundia, shadow economy expansion, possession.

\section{INTRODUCTION}

At the turn of the XX-XXI centuries, in accordance with the requirements of fast-flowing economic history, the priorities of production factors location are corrected, and the focus in scientific research is given to information resources, nano-and biotechnologies, creative human potential [1]. At the same time, the land, which is still an important resource of agricultural production and is an indispensable condition for life reproduction, often stands in the background. Whereas not only within a single country but also globally, the relevance and value of this limited, unique and non-reproducible resource of agriculture increases, especially taking into account the consequences of industrial and post-industrial development, urbanization processes, ensuring food security (acting as the main goal of agricultural policy, recognized as a guarantee of the real sovereignty of any country, an integral part of its national security) [2, 3]. Moreover, according to experts, there is a reason to believe that in the coming decades, the oil era will be replaced when the problem of food shortage comes first and food becomes the leading factor in world politics, thereby the role of land resources and the economic realization of land ownership increase immeasurably. In the institutional sense, it is important who owns the resource whereby food is created, and the effective implementation of land ownership determines the level of food security $[4,5]$.

\section{RESULTS AND DISCUSSION}

The importance of land resources, considered primarily as the base for the production of agricultural raw stores and provisions, increases with the growth of the world population. Thus, it took 10,000 years for the number of inhabitants of the planet to reach 1 billion (1800), about 130 years to double the population (2 billion - 1930), and only about 40 years for its next doubling (1974), which gave reason to talk about the demographic explosion. Accordingly, the growing number of the world population is demanding more and more food: global cereal demand is showing a steady increase of $2.3 \%$ on average. Taking into account the fact that famine has become one of the world's most serious problems (more than 795 million people are starving on earth today, and the need for food worldwide is growing), that every 12-14 years the Earth population increases by 1 billion, and approximately it can rise to 10 billion by 2050 (in addition, according to forecasts, the 
number of people of retirement age will exceed all other age groups for the first time in the history of mankind), then we may need to double the volume of world food production [6], which clearly will require expansion of arable land which resources are very limited in the world [7].

It should be noted that the location of the leading agricultural powers as the owners of the largest land resources in the world (Fig. 1. [8]) changes substantially in terms of arable land per 1 person (the top line is Australia - 2.47 hectares, Canada - 1,46 hectares, Argentina - 0,89 hectares and Russia - 0.86 hectares, while in the most densely populated countries (China and India), these figures are the lowest $(0.43$ hectares and 0.17 hectares respectively)), there is also a huge gap on such important characteristics of the relationship between population and Earth territory as the population density (at the beginning of 2016, it was equal to on average of 54.3 people per square kilometer (for example, in the countries with the highest density: Monaco - 16500 people per sq. km., Singapore - 7326 people per sq. km.; the countries with the lowest density: Australia - 3 people per sq. $\mathrm{km}$, Namibia - 3 people per sq. km, Mongolia - 2 people per sq. $\mathrm{km}$ [9]). Indicators of population density are as follows: in Russia - 8, in Kazakhstan - 6, in the United States - 33. [9, p. 17]

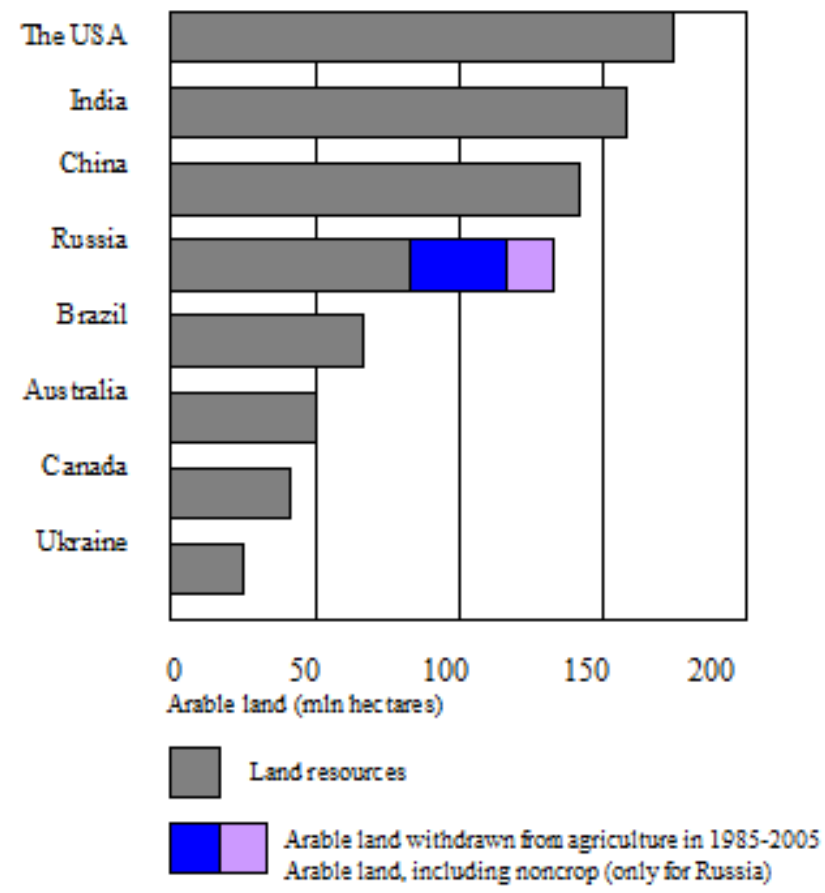

Fig. 1. Land resources of the world leading agricultural powers

At the same time, the decline in the agricultural land sufficiency as the world population grows, as well as the process of urbanization, soil erosion, desertification and other destructive processes on a global scale, is a universal trend: every decade $7 \%$ of fertile soils are lost in the world and every two years 12 million hectares of deserted lands are added, respectively, the specific area of arable land per inhabitant is also constantly reduced (Fig.2) [10]. Although, according to FAO data, there are more than 3 billion hectares of potentially suitable agricultural land in the world (only 25 countries in Africa do not use 400 million hectares of fertile land), but their introduction into circulation requires huge investments of labor and funds that these countries do not yet have. In the current conditions of the huge and steadily growing demand for land suitable for agricultural production in the world, today only the United States and Russia have free land resources.

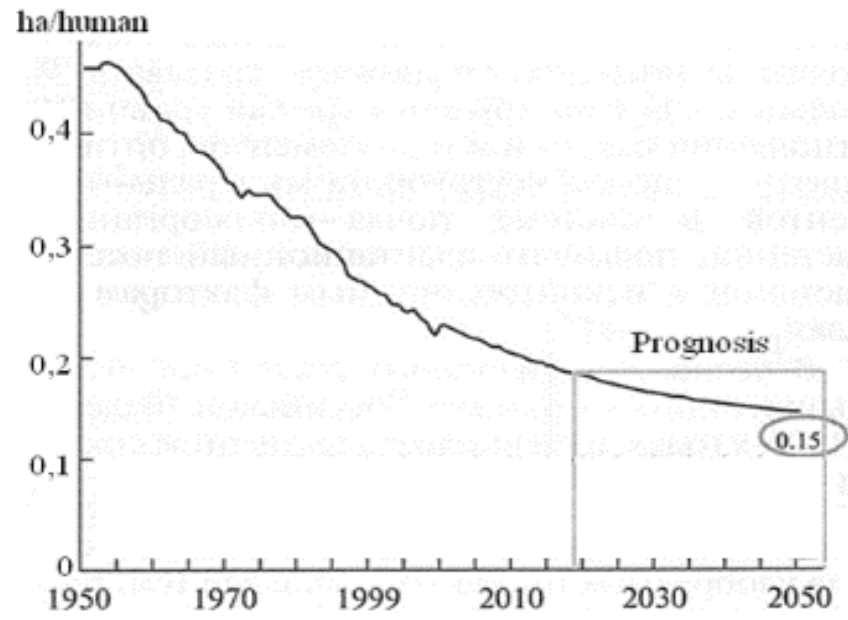

Fig. 2. Dynamics of arable land area per person in the world, hectares / person.

In this regard, it seems that Russia has unique agricultural opportunities and potential, as it is one of the world leaders in arable land area, possessing almost $40 \%$ of the world areas of black earth-soils characterized by the highest natural fertility, and, therefore, competitive advantages, the most important of which is the extensive nature of Russian agriculture, which allows one to produce environmentally friendly products in the vast expanses of the country, the volumes of which are limited all over the world [11, 12]. Accordingly, in specific circumstances, Russia has a serious potential for land resources, and it would be able to present itself as an exporting country for a significant part of the growing population of the planet [13].

However, we regret to note that the actual scenarios of the reform, which began in 1990 with the act "Land Reform", gave rise to deformed models of economic realization of land property and caused the growth of its "shadow economy expansion". The doctrinal basis of Russian reforms was the neoclassical theory, implicitly and sometimes obviously interpreting ownership only as the right for private property. Hence, its framework and heuristic capabilities do not allow to determine the underlying cause of the growing dynamics of negative results of the land reform, in need of significant adjustment, modern liberal dogma does not take into account the current complex of sufficiently significant factors that objectively "blow upon" the priority of private ownership of agricultural land at the lowest level. The scientific explanation of the existing paradoxes, their corresponding assessment and development of constructive ways of solving the systemic contradictions require an appeal to the political and economic interpretation of land property and its reform on the basis of a reproductive approach. 
Land reform, being carried out for more than a quarter of a century, is based on the idea of turning Russian peasants into title owners by assigning and allocating land plots to them. In this regard, the problem of the victims, deceived land shareholders, becomes especially urgent in Russia. If it is continued and completed in the form it was started in, the free land market will inevitably evolve towards the formation of a layer of latifundists. It is possible to state that today there is a considerable part of owners of the land shares which are not connected directly with agrarian production, representing the rentier group which is appropriating land rent in a parasitic way and which will be compelled to be paid by the society; a high-yield speculative land market, connected with the cheap purchase of land shares from rural residents, followed by their resale at a market price with a change in the category of land, is flourishing; one of the manifestations of that is a dynamically growing wave of detected crimes of officials at different levels of government in the last decade throughout the country, related to violations of legislation in the field of land management. The current state of affairs, in fact, is a confirmation of the statement of T. J. Dunning quoted by K. Marx in the "Capital" that in the presence of sufficient profit the fearful nature of capital changes, and he acquires courage, tramples all human laws, commits crimes, risking even under the threat of the gallows [14]. According to the information available, foreign funds (primarily venture funds), including those previously exported from Russia [5] are involved in shadow land deals, about half of large Russian agricultural producers from 35 to $99 \%$ of shares directly or indirectly belong to foreign owners. In addition, land speculation has now received new incentives associated with higher agricultural land prices caused by relatively good crop performance over the past few years (see Table 1).

TABLE I. DYNAMICS OF PRICES OF THE MOST VALUABLE FARMLAND IN RUSSIA (PER 1 HECTARE) (COMPILED BY [15])

\begin{tabular}{|c|c|c|c|c|c|}
\hline & $\begin{array}{c}\text { Price } \\
\text { (RUB 000s) }\end{array}$ & $\begin{array}{c}\text { Price } \\
\text { (dollars) }\end{array}$ & $\begin{array}{c}\text { Price increase } \\
\text { (in 2012-17) } \\
(\%)\end{array}$ & $\begin{array}{c}\text { Price increase } \\
\text { On average } \\
\text { per year (\%) }\end{array}$ & $\begin{array}{c}\text { Price increase } \\
\text { in 2017 } \\
(\%)\end{array}$ \\
\hline $\begin{array}{c}\text { The South of } \\
\text { Russia }\end{array}$ & $95-126$ & $1450-2100$ & 220 & 17,3 & 60 \\
\hline $\begin{array}{c}\text { Central Black } \\
\text { Earth Region }\end{array}$ & $35-41$ & 550 & 200 & 15,2 & 25 \\
\hline $\begin{array}{c}\text { The Volga } \\
\text { Region }\end{array}$ & 18 & 300 & 140 & 7 & 16 \\
\hline
\end{tabular}

According to expert estimates, in 2012-2017 prices of the most valuable farmland in the South of Russia increased 2.2 times (on average by $17.3 \%$ annually), in the Central Black Earth Region - 2 times (by $15.2 \%$ annually), and in the Volga region - 1.4 times (by 7\% annually); in 2017 alone, prices increased by $60 \%, 25 \%$, and $16 \%$, respectively. At the same time, the highest land price in Russia is in the Krasnodar territory, it equals 2100 dollars per hectare, and it is about three times cheaper than those that are significantly inferior in terms of natural conditions Eastern Europe (Romania, Poland, Lithuania), not to mention the level of agricultural land prices in the UK - an average of 20 - 30 thousand dollars, as well as in the United States, where cultivated arable land for investors costs in the range of $5-12$ thousand dollars. Hence, the relative low-price of the Russian land ensures sustained interest in its purchase by foreign investors. It is possible that in many respects this explains the presence of a large part (according to various estimates, from $40 \%$ to $45 \%$ ) of the domestic grain market under the control of foreign companies (BungeLimited, CargillInc., GlencoreInt.AG, LouisDreyfusGroup, Nestle S. A. and others). Thus, the practice itself confirms the evidence that the legalization of private ownership of agricultural land inevitably forms a shadow turnover of land and provides a direct ejection of land into the sphere of speculation in the conditions of its today's extremely low price. In addition, the technology of land grabbing by money capital has now been perfected, and as soon as the lands (usually the most valuable) become a commercial asset and the subject of financial speculation, they inevitably pass into the hands of shadow buyers and creditors $[13,16]$. The world has already assessed the impact of the transfer of land property to foreigners in developing countries as a way of investing in agriculture, also the negative experience of the so-called "land grabbing", the impact of foreign investors on the price of land, the possibility of access to land for rural residents are summarized; the facts of their hollowing-out from agricultural use in rural areas are noted.

The essence of the constructive position is the decisive rejection of ultra-liberalist postulates, the pivot of agrarian reform in the direction of maximum favoring entrepreneurial land ownership, the creation of a mass producer of agricultural products while maintaining title ownership of the state. This position is based on the fact that 1) land ownership is an internal strategic factor of land ownership relations, hence it is reasonable to believe that this institution is a necessary and sufficient condition for stimulating the development of agricultural production and entrepreneurship, effective land reforms in Russia; 2) in accordance with the theoretical provisions and foreign practice for profitable agricultural production organization legal ownership is not required, entrepreneurs can quite effectively run a business on leased land; 3 ) sustainable development and effective implementation of land ownership are possible under state ownership, and it is enough to develop the Institute of land lease, allowing the rational control of production and financial flows. The next step in the reproduction support of the agricultural producer is to improve access to the sources of motor capacities (fuels and lubricants, electricity, etc.) by returning part of the exported raw materials to domestic processing and increasing their supply in the domestic market, possibly using the cooperation opportunities of the EAEU formation to implement this direction. In addition, the actions of the West are forcing today a new approach to the strategy of food and economic security, and, in particular, to the advance refining of resources (primarily hydrocarbons), and thereby reducing the costs of agricultural producers will turn Russia's resource advantages into competitive ones. The end of the reproduction cycle involves ensuring the sale of agricultural products without the pressure of a multi-link system of resellers and monopolization of markets. A special problem is the level of provision with agricultural machinery (the immediacy of the problem of which for Russia is associated with the worn-out of fixed assets in the field of agricultural machinery and the lack of internal sources of modernization), and ways to solve 
the problem of support for agricultural machinery enterprises effectively are not found (this applies to fertilizer production). It seems that these problems should be addressed comprehensively within the framework of a single perspective program for the development of the agro-industrial complex. Unfortunately, the task of its development at the state level is not set, while, taking into account the current realities of food security, the need to develop this program is imminent.

\section{CONCLUSION}

The way out of the current and deepening crisis situation in the field of land ownership relations and the development of a positive concept of land reform adjustment, affecting the conflicting interests of different actors, and, above all, direct producers of agricultural products, is associated with a strong rejection of ultra-liberalist postulates. Under such development of market processes, rights of use and ownership but not legal ownership rights will have priority in land transactions. The buying of the right to lease requires less financial lump sum funds than the purchase of land, hence, many farmers will have free access to the main agricultural resource, thereby economically unhindered access to the latter will reduce barriers to entry into this industry of producers who do not have sufficient funds to purchase land, reduce marginal costs, expand the supply of food products and as a result will become a new impetus for the development of entrepreneurship in the industry as a whole.

\section{References}

[1] E.V. Maksutina, A.N. Makarov, E.F. Nazmeev, E.S. Alpatova, Assessment of economic efficiency of investments into the human capital in modern conditions, Life Science Journal, 2014, V. 11, № 6s, pp. 376-379.

[2] P. McMichael, M. Schneider, Food Security Politics and the Millennium Development Goals, Third World Quarterly, 2011, Vol.32, №1.
[3] G. Lawrence, Ph. McMichael, The Question of Food Security, International Journal of Sociology of Agriculture and Food, Vol. 19, №2, 2012.

[4] J. Duncan, D. Barling, Renewal through Participation in Global Food Security Governance: Implementing the International Food Security and Nutrition Civil Society Mechanism to the Committee on World Food Security, International Journal of Sociology of Agriculture and Food, 2012, Vol. 19, №2.

[5] A. N. Makarov, Food security in the context of land ownership reform (assessment, constructive position), Land Management, cadastre and land monitoring, 2017, No. 11, pp. 19-25.

[6] Robert J. Samuelson, Global food crisis. Source: The Washington Post. http://www.inopressa.ru/article/16mar2011/wp/crisis.html

[7] O. S. Sukharev, Institutional problems of ensuring food security of Russia, National interests: priorities and security of Russia, 2015, No. 6 (291), p. 45

[8] I. Rubanov, System error for one hundred billion, Expert, 2008, No. 22 (June 2-8), p. 42.

[9] Proceedings of the international scientific-practical conference dedicated to the 85th anniversary of the Russian National Research Institute of Agricultural Economics, Part I, Moscow, FSBSI RNSRIAE, 2015. Retrieved from: http://www.vniiesh.ru/documents/document_20710_

[10] V.N. Kudeyarov, Assess the nutritional degradation of arable soils of Russia, Herald of the Russian Academy of Sciences, 2015, Vol.85, No. 9, pp. 771-775.

[11] N.G. Bagautdinova, S.K. Eshugova, U. Saipullaev, E.A. Karasik, Methods of technology commercialization in projects of the agrofood system (AFS) development. World Applied Sciences Journal, 2013, no. 27(13), pp. 48-52.

[12] T.N. Isaeva, L.N. Safiullin, N.G. Bagautdinova, R.N. Shaidullin, Aspects of a multi-level study of competitive performance of objects and subjects of economic management. World Applied Sciences Journal, 2013, no. 27(13), 116-119.

[13] S.Yu. Glazyev, On food security in Russia: Report of the panel of experts of the Izborsk club, under the leadership of academician, Retrieved from: http://izborsk-club.ru/content/articles/1725/

[14] K. Marx, Capital. Criticism of political economy.Vol.1.kN.1. The process of production of capital, Moscow: Politizdat, 1983.

[15] A. Chablin, Who and at what price buys Russian soil. Retrieved from: https://svpressa.ru/economy/article/166435/

[16] S. Wegren, Food Security and Russia's 2010 Drought, Eurasian Geography and Economics, 2011, Vol.52, №1. 